\title{
Investigating the effects of global financial crisis on stock price and operating profit: Evidence from Tehran Stock Exchange
}

\author{
Seyedeh Shideh Dianat Jahromi ${ }^{\mathbf{a}^{*}}$, Hossein Karbasi Yazdi ${ }^{\mathrm{b}}$ and Ahmad Sarlak ${ }^{\mathrm{c}}$
}

${ }^{a}$ M.A. in Accounting, Islamic Azad University, Arak Branch, Arak, Iran

${ }^{b}$ Department of Accounting, Islamic Azad University, South Branch, Tehran, Iran

${ }^{c}$ Department of Economy, Islamic Azad University, Arak Branch, Arak, Iran

\section{H R O N I C L E}

\section{Article history:}

Received May 15, 2013

Received in revised format

17 August 2013

Accepted 18 August 2013

Available online

August 202013

Keywords:

Financial crisis

Operating profit of the capital

market

Stock price of the product

Economic recession

\begin{abstract}
A B S T R A C T
In some decades, capitalism countries have suffered from financial crises and the financial crises have created economic recession started from the country of origin and distributed to other counties. The purpose of this paper is to study the global financial crisis effects on the stock price as well as operating profit of some listed companies in Tehran Stock Exchange(TSE). This research shows the difference between operating profit and the price of the products of the firms before and after the global financial crisis. The aim of this research is to study the effects of the global financial crisis on 133 TSE firms over the period 2004-2011 by considering two periods: Before/after crisis, i.e. 2004-2008 and 2008-2011. The results of testing different hypotheses show that there was a significant difference between the operating profit and the stock price of the firms before and after the global financial crisis on the different industries of the Iranian companies.
\end{abstract}

\section{Introduction}

Inspecting the history of the world financial crisis shows that two major crises, crises of 1929 and 2007, affected the whole world during the outbreak where the first one caused the stock market crash and the second one caused to credit markets decline. The similarities between the roots of the crisis in 1929 and the recent crisis, is somewhat surprising (Peihani, 2008). In both crises there is a bubble that was seen in the crisis of 1920 in the stock market and in the recent crisis in the real estate market. In either mode, the bubbles generated due to the wrong policies of the Federal Reserve of United States.

Unlike today, that the central bank's role is maintaining stability in the general level of prices and production rate, in 1914 the only important goal of this organization, was to preserve the value of the

*Corresponding author.

E-mail address: Gitinejad_b@yahoo.com (S.S. Dianat Jahromi) 
money. Also in this period, all the major world currencies were based on the gold standard system that linked the money value of country to the amount of existing gold. Because each country had a fixed amount of money as compared with gold, the value of one currency was fixed quantity as compared with another one. In that situation, controlling the volume of money in the economy depends on the amount of gold and this dependence caused the governments not to increase their expenditure more than the authorized limit. The result was that inflation was remained low. In December 1930, the world entered the sixteenth month of Great Depression, the stock market experienced a 50\% drop in index, benefits were reduced to half and the world's industrial production were reduced by nearly $20 \%$. Interestingly, it is good to know that in the recent crisis, and in May that sixteen months were spent since the crisis, like the crisis of 1929 , the stock market lost $50 \%$ of its value, there was a $50 \%$ reduction on rate of profit and the world's industrial production were reduced by $20 \%$. But the difference is that in the 1930 s, after 18 months, the economic crisis reached its climax and in that time, the stock market experienced the $50 \%$ reduction and the world's industrial production were reduced by $40 \%$. But in the recent crisis it did not happen and instead, the markets were established, financial institutions were not under the harsh conditions of the 1930s and also it was observed that the positive economic signs have emerged. This difference is due to the reaction of the policy makers. The effects of the financial crisis on all the communities start from government to financial institutions and then it goes to the society. Observing the institutional crisis in the years near the crisis, shows that the firms have suffered significant decline about all the selected financial indices. This was not desirable for the beneficiaries of the financial institutions particularly shareholders and it was the first incentive for sale of shares by the shareholders of these institutions and it is considered the primary factor of developing crisis. Inspecting the financial crisis in 2008 shows that this crisis is rooted back in the housing loan market and in fact its occurrence have begun since September 2001 with artificially decrease of the interest rates. This recession was begun in United States and after a time, it influenced the world economy for almost a decade.

There is no doubt that the international financial crisis that started in the United States will cast its impacts on all countries of the world, developed or even developing countries but the effects may vary from one country to another for different reasons (Johnson et al., 2000). The GCC countries are not exception from these negative impacts of this severe crisis. The negative impacts of the crisis on Persian gulf countries happened for many reasons such as decline on oil prices, decrease in the value of US\$ and consequently decrease in the assets owned by these countries in US\$ and finally a case of economic stagnation that prevailed in the world with effects starting to appear. Therefore, this would be reflected on the real sector in the economies creating a series of negative impacts through decrease of the world demand for exports of GCC countries of oil, petrochemicals and aluminum. In addition, increased inflation rates with decreased interest rates also influence in a decrease in real interest with an accompanying decrease in incentives for saving and consequently investment and economic development (Abdelbaki, 2010).

Abdelbaki (2010) evaluated the economic impacts of the global financial crisis on GCC countries and reported that the big reserves of foreign currencies achieved by the GCC countries in the past few years could help increase their ability to bear the impacts of the financial impacts on one hand and their capability to adopt expansionary policies through pumping liquidity to absorb the regressive impacts of the crisis on the other. The study recommended the necessity of taking precautionary procedures for the effects, which could result from the expansionary policies effective in GCC countries. Bancel and Mittoo (2011) performed an investigation to gain some insights into how managers perceive and achieve financial flexibility and its value in coping with the 2008 global financial crisis. They concluded that firms with high financial flexibility suffered less from the crisis. Khorshid (2012) recommended considering social responsibility and accountability to the mandate of Shari'ah advisory boards in order to prevent financial crises. Lo (2012) reviewed a diverse set of 21 books on the crisis, 11 written by academics, and 10 written by journalists and one former Treasury Secretary. He reported no single narrative emerges from this broad and often contradictory collection 
of interpretations. Mohsen et al. (2011) discussed how financial organizations could overcome the global business crisis. Schich (2010) investigated the conditions of insurance companies during the financial crisis. Subrahmanyam (2009) attempted to trace out different triggers, trails and travails of the present crisis, with a view to recommend solutions or treatments for the global financial crisis of 2008-09. For example, one of the triggers detected was the prolonged implementation of low interest rate policy. The author explained that some new lessons had been learnt from the current financial crisis, the most important of them being the necessity for retooling the finance and economics models. Tayebi and Ramezani (2011) explored the impact of financial crisis on trade flows of steel industries in the major Asian-Pacific steel producing countries. They applied a static and dynamic panel data analysis and examined the hypothesis that the global financial crisis had a negative impact on Asia-Pacific bilateral steel trade flows. They also investigated the impact of regional trade integration in bilateral steel trade in Asia and Pacific. The underlying assumption was that such integration contributed to increase trade relationships and possibly adjusted the imposed expenses of financial crisis on the sector. Trabelsi (2011) investigated the effect of the financial crisis on the global economy and tried to realize whether the Islamic financial system could help or not.

\section{Framework of theoretical concepts and research hypotheses}

Financial crisis: the financial crisis is a comprehensive term, which includes the existing of the crisis in variables of the financial part of the economy. The financial crisis is defined as the negative effects in the balance of payments, negative effects in the value of currency, financial debt crisis, banking crisis (bank failures), the international reserves crisis and the stock market crisis. The independent variable of this research is associated with the effects of the global financial crisis and a dummy variable is implemented to recognize the effect. The dummy variable receives a zero value from 2004 to 2007 because there was no global financial crisis and it is equal to one from 2008 to 2011 where there was some global financial crisis. The other variables include stock price as well as production prices. This figure is extracted from official statements of the firms reported to TSE. Operating profit in another variable, which is the difference between the incomes and operating costs. This variable represents the operating loss or profit. The following states the first two hypotheses of this survey,

Main hypothesis (1): There is a significant difference between the stock prices of the products before and after the global financial crisis.

Main hypothesis (2): There is a significant difference between the operating profit of the companies before and after the global financial crisis.

The research method is correlation in terms of the nature and content and it is applied and practical in terms of the goal. The research is conducted in the framework of deductive reasoning. It means that the theoretical fundamentals and background of the research are extracted from the library studies, surfing the net and studying the quarterly seasons and gathering information to accept the hypothesis is done deductively. To achieve the stock price of the products and also operational benefits, the financial statements of the companies are used and also the global financial crisis is considered as the dummy variable that is equal to 1 at the time of existing crisis and zero, otherwise.

This research is conducted on the accepted companies in Tehran Stock Exchange over the period 2004-2011. Companies that had the following conditions in the above period have been eliminated from the population by the systematic elimination method and eventually 133 companies were tested.

- Companies that have been out of stock market for a period.

- Companies that have been entered to the stock within the period of study.

- Companies that have had a change in their fiscal year during the research period.

- All holding firms as well as financial firms were excluded from the study. 
- Companies whose shares were either halted or suspended for a period of more than three months were delisted from this list.

- Number of companies that their fiscal year does not end to March, 19th (homogeneous) (because of monotony of fiscal year in terms of the activity)

\section{The results}

In this section, we present details of our findings on testing the hypotheses of this survey. We first look at some basic statistics,

Table 1

Descriptive statistics of the variable before the crisis

\begin{tabular}{lcccc}
\hline \multirow{2}{*}{$\begin{array}{l}\text { Variable } \\
\end{array}$} & \multicolumn{2}{c}{$\begin{array}{c}\text { Descriptive statistics of the variable before the } \\
\text { global financial crisis }\end{array}$} & $\begin{array}{c}\text { Descriptive statistics of the variable after the global } \\
\text { financial crisis }\end{array}$ \\
\cline { 2 - 5 } & Stock price & Operating profit & Stock price & Operating profit \\
\hline No. of observations & 532 & 532 & 532 & 532 \\
Average & $336,891.69$ & $120,547.96$ & $338,433.33$ & $118,548.42$ \\
Standard deviation & 265992.114 & 834640.9058 & 3571661.795 & 825835.6741 \\
Median & 195084 & 49474 & 332490 & 66068 \\
Skewness & $8 / 697$ & $7 / 540$ & $8 / 737$ & $7 / 158$ \\
Minimum & 5640 & 348850 & 4819 & 144248 \\
\hline Maximum & 45707557 & 12545487 & 91567956 & 12945066 \\
\hline
\end{tabular}

In order to test the research hypotheses, the method of combining the sectional and time series data has been implemented and there were 1064 observations before and after the global financial crisis. The first step to do statistical tests, we need to make sure about the normality of the data. In order to test the normality, Kolmogorov-Smirnov test is used. If the probability amount of this test is greater than 0.05 , the data are normal with the $95 \%$ confidence and vice versa. The result of this test shows that all the variables are normally distributed because significant level of the variables is more than 0.05 .

\section{Table 2}

Testing normality with Kolmogorov-Smirnov test

\begin{tabular}{lcccc}
\hline & \multicolumn{2}{c}{ Before the global financial crisis } & \multicolumn{2}{c}{ After the global financial crisis } \\
& Stock price & Operating profit & Stock price & Operating profit \\
\hline No. of observations & 532 & 532 & 532 & 532 \\
Average & $336,891.69$ & $120,547.96$ & $338,433.33$ & $118,548.42$ \\
Standard deviation & 265992.114 & 834640.9058 & 3571661.795 & 825835.6741 \\
\hline Z Kolmogorov Smirnov & 1.448 & 1.612 & 1.412 & 1.404 \\
\hline Sig. & 0.0688 & 0.0681 & 0.0674 & 0.0701 \\
\hline
\end{tabular}

The results of the first hypothesis test:

Main hypothesis (1): There is a significant difference between the stock prices of the products before and after the global financial crisis.

$\mathrm{H}_{0}: \mu_{1}=\mu_{2}$ : There is not a significant difference between the stock prices of the products before and after the global financial crisis.

$\mathrm{H}_{1}: \mu_{1} \neq \mu_{2}$ : There is a significant difference between the stock prices of the products before and after the global financial crisis.

Table 3 shows details of testing the first hypothesis of this survey. 
Table 3

The results of the t-test on relationship between global financial crisis and stock prices of the products

\begin{tabular}{|c|c|c|c|c|c|c|c|c|c|c|}
\hline Independent & \multicolumn{2}{|c|}{ No } & \multicolumn{2}{|c|}{ Average } & \multicolumn{2}{|c|}{ Standard deviation } & $\begin{array}{c}\mathrm{t}- \\
\text { statictics }\end{array}$ & $\mathrm{df}$ & Sig & Average \\
\hline \multirow{2}{*}{$\begin{array}{c}\text { Global } \\
\text { financial } \\
\text { crisis }\end{array}$} & After & Before & After & Before & After & Before & \multirow[b]{2}{*}{2.172} & \multirow[b]{2}{*}{531} & \multirow[b]{2}{*}{0.028} & \multirow[b]{2}{*}{1541.64} \\
\hline & 532 & 532 & $338,433.33$ & $336,891.69$ & 3571661.795 & 265992.114 & & & & \\
\hline
\end{tabular}

In Table 3, because of the $\mathrm{F}$ value, which is equal to 9.579 , the significance level is under 0.05 . Therefore, the variances are not equal so an independent t-test with adjusted degrees of freedom is used. In the next level, because the means are not equal, we consider the significance level. Because the $t$ value is 2.172 and the significance level of 0.028 , which is less than 0.05 , therefore with $95 \%$ confidence we can say that the means of two groups are not equal or there is a significant difference between the stock prices of the products before and after the global financial crisis.

The results of the second hypothesis test:

Main hypothesis (2):

There is a significant difference between the operating profit of the companies before and after the global financial crisis.

$\mathrm{H}_{0}: \mu_{1}=\mu_{2}$ : There is not a significant difference between operating profit before and after the global financial crisis.

$\mathrm{H}_{1}: \mu_{1} \neq \mu_{2}$ : There is a significant difference between operating profit before and after the global financial crisis.

Table 4 summarizes the results of our investigation.

Table 4

The results of the t-test to investigate the relation between global financial crisis and operating profit

\begin{tabular}{|c|c|c|c|c|c|c|c|c|c|c|}
\hline $\begin{array}{l}\text { Independent } \\
\text { Variable }\end{array}$ & \multicolumn{2}{|c|}{ No } & \multicolumn{2}{|c|}{ Average } & \multicolumn{2}{|c|}{ Standard deviation } & $\begin{array}{c}\mathrm{t}- \\
\text { statistics }\end{array}$ & $\mathrm{df}$ & Sig & Average \\
\hline \multirow{2}{*}{$\begin{array}{c}\text { Global } \\
\text { financial } \\
\text { crisis }\end{array}$} & After & Before & After & Before & After & Before & \multirow[b]{2}{*}{1.617} & \multirow[b]{2}{*}{531} & \multirow[b]{2}{*}{0.014} & \multirow[b]{2}{*}{1963.54} \\
\hline & 532 & 532 & $118,548.42$ & $120,547.96$ & 825835.6741 & 834640.9058 & & & & \\
\hline
\end{tabular}

In Table 4 , because of the $F$ value, which is equal to 7.518 , the significance level is above 0.05 . Therefore the variances are equal. In the next level, because the means are not equal, we consider the significance level. Because the $t$ value is equal to 1.617 and the significance level is less than 0.05 , therefore with $95 \%$ confidence we can say that the means of two groups are not equal or there is a significant difference between the stock prices of the products before and after the global financial crisis.

\section{Discussion and conclusion}

In this paper, we have presented an empirical investigation to study the impact of recent US financial crisis on Tehran Stock Exchange. The survey has gathered the necessary information four years before and after the 2008 financial crisis and using some statistical test has determined that there was a difference between the performances of some selected firms before/after US financial turmoil. 
According to the results, we can say that:

1. The stock prices of the products before the global financial crisis were more than the prices after the global financial crisis in the accepted companies by Tehran Stock Exchange.

2. The operating profits before the global financial crisis were more than the operating profit after the global financial crisis in the accepted companies by Tehran Stock Exchange.

Note that the survey has some limitations, which might influence the results of our survey. For instance, we only selected firms whose financial statements were officially audited. This study can be extended future by considering the effects of financial crisis in terms of different industries, measuring the risk of bankruptcy, transparency risk, etc. and we leave it as future research for interested researchers.

\section{References}

Abdelbaki, H. H. (2010). Assessing the impact of the global financial crisis on GCC countries. Journal of Business \& Economics Research (JBER), 8(2), 139-151.

Bancel, F., \& Mittoo, U. R. (2011). Financial flexibility and the impact of the global financial crisis: Evidence from France. International Journal of Managerial Finance, 7(2), 179-216.

Johnson, S., Boone, P., Breach, A., \& Friedman, E. (2000). Corporate governance in the Asian financial crisis. Journal of financial Economics, 58(1), 141-186.

Khorshid, A. (2012). Adding social responsibility and accountability to the mandate of Shari'ah advisory boards. Available at SSRN 2189864.

Lo, A. W. (2012). Reading about the financial crisis: A twenty-one-book review. Journal of Economic Literature, 50(1), 151-178.

Mohsen, A., Abdulla, M., \& Jalal, A. (2011). How financial organizations can overcome the global business crisis. International Journal of Business and Management, 6(2), 101-111.

Peihani, M. (2008). An analysis of contributing trends, policies and failures. The Global Financial Crisis of / Banking \& Finance Law Review.

Schich, S. (2010). Insurance companies and the financial crisis. OECD Journal: Financial Market Trends Volume 2009 - Issue 2@ OECD.

Subrahmanyam, G. (2009). Global financial crisis of 2008-09: Triggers, trails, travails, and treatments. The IUP Journal of Applied Economics, 8(5-6), 32-47.

Tayebi, S.K., \& Ramezani, F. (2011). Financial crisis and steel trade integration in Asia and pacific, A static and dynamic Analysis. International Journal of Business and Development Studies, 3(1), 5-28.

Trabelsi, M. A. (2011). The impact of the financial crisis on the global economy: can the Islamic financial system help?. Journal of Risk Finance, 12(1), 15-25. 